\title{
Rippling Muscle Disease 2
}

National Cancer Institute

\section{Source}

National Cancer Institute. Rippling Muscle Disease 2. NCI Thesaurus. Code C148325.

An autosomal dominant condition caused by mutation(s) in the CAV3 gene, encoding caveolin-3. It is characterized by mechanically triggered contractions of skeletal muscles.

Limb-girdle muscular dystrophy type $1 \mathrm{C}$ is an allelic disorder with an overlapping phenotype. 